\title{
Self-care of people with intestinal ostomy: beyond the procedural towards rehabilitation
}

\author{
Autocuidado de pessoas com estomia intestinal: para além do procedimental rumo ao alcance da reabilitação
}

Autocuidado de personas con estoma intestinal: para además del procedimental rumbo al alcance de la rehabilitación

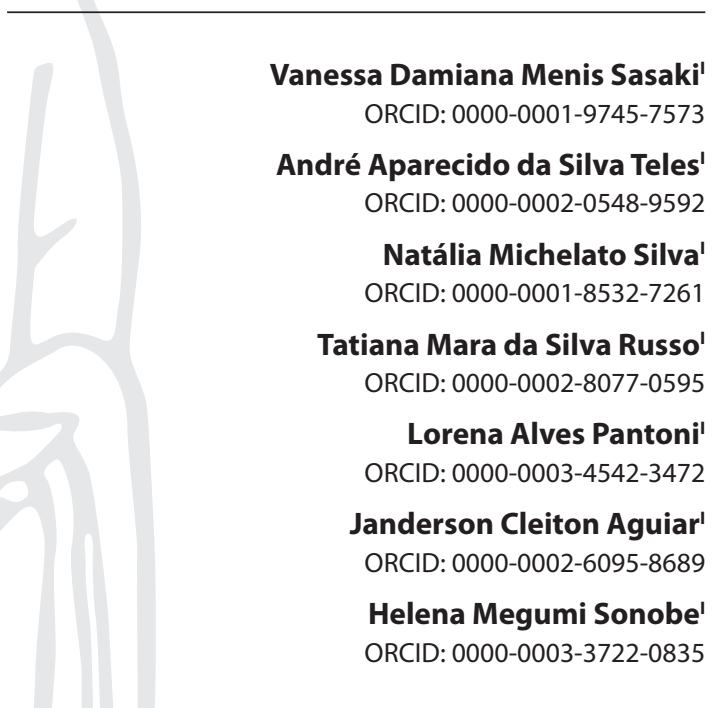

'Universidade de São Paulo. Ribeirão Preto, São Paulo, Brazil.

How to cite this article: Sasaki VDM, Teles AAS, Silva NM, Russo TMS, Pantoni LA, Aguiar JC, et al. Self-care of people with intestinal ostomy: beyond the procedural towards rehabilitation

Rev Bras Enferm. 2021;74(1):e20200088. doi: http://dx.doi.org/10.1590/0034-7167-2020-0088

Corresponding author:

Vanessa Damiana Menis Sasaki

E-mail: vanessasasaki@hotmail.com

EDITOR IN CHIEF: Antonio José de Almeida Filho ASSOCIATE EDITOR: Hugo Fernandes

Submission: $07-08-2020$

Approval: 10-15-2020

\section{ABSTRACT}

Objectives: to interpret the self-care experience of people with intestinal ostomy registered in an ostomy program, based on the framework of the Social Model of Disability. Methods: qualitative exploratory research, with the participation of nine people with intestinal ostomy, based on the Social Model of Disability. Results: majority were elderly, married, male with colostomy due to colorectal neoplasia. The self-care of these people was analyzed in two thematic groups: "Interdisciplinary assistance needed for people with intestinal ostomy" and "Self-care for the rehabilitation of the person with intestinal ostomy". It was proved that there was a need for a specialized health team, offering information on disabilities, teaching self-care and perioperative follow-up. Final Considerations: when the social barriers of physical disabilities are overcome in the context of assistance for health and life, self-care will go beyond the reductionist vision of procedural care, towards comprehensive care, favoring the achievement of rehabilitation and the quality of survival.

Descriptors: Patients; Ostomy; Self Care; Disabled Persons; Rehabilitation.

\section{RESUMO}

Objetivos: interpretar a experiência de autocuidado de pessoas com estomia intestinal cadastradas em um programa de ostomizados, fundamentando-se no referencial do Modelo Social da Deficiência. Métodos: estudo exploratório qualitativo, com participação de nove pessoas com estomia intestinal, pautando-se no Modelo Social da Deficiência. Resultados: maioria idosa, casada, do sexo masculino e com colostomia por neoplasia colorretal. Analisouse o autocuidado dessas pessoas em dois núcleos temáticos: "Assistência interdisciplinar necessária às pessoas com estomia intestinal" $\mathrm{e}$ "Autocuidado para a reabilitação da pessoa com estomia intestinal". Mostrouse a necessidade de equipe de saúde especializada, com oferecimento de informações sobre deficiência, ensino do autocuidado e seguimento perioperatório. Considerações Finais: quando as barreiras sociais da deficiência física forem superadas no contexto da assistência à saúde e de vida, o autocuidado extrapolará a visão reducionista do cuidado procedimental, rumo ao cuidado integral, favorecendo o alcance da reabilitação e da qualidade de sobrevivência.

Descritores: Paciente; Estomia; Autocuidado; Pessoas com Deficiência; Reabilitação.

\section{RESUMEN}

Objetivos: interpretar la experiencia de autocuidado de personas con estoma intestinal registradas en un programa de ostomizados, fundamentándose en Modelo Social de la Discapacidad. Métodos: estudio exploratorio cualitativo, con participación de nueve personas con estoma intestinal, pautándose en Modelo Social de la Discapacidad. Resultados: mayoría anciana, casada, sexo masculino y con colostomía por neoplasia colorrectal. Analizado autocuidado de esas personas en dos núcleos temáticos:"Asistencia interdisciplinar necesaria a las personas con estoma intestinal" $y$ "Autocuidado para la rehabilitación de persona con estoma intestinal". Mostrada necesidad del equipo de salud especializada, con ofrecimiento de informaciones sobre discapacidad, enseñanza del autocuidado y seguimiento perioperatorio. Consideraciones Finales: cuando las barreras sociales de la discapacidad física se rebasen en el contexto de la asistencia de salud y de vida, el autocuidado extrapolará la visión reduccionista del cuidado procedimental, rumbo al cuidado integral, favoreciendo el alcance de la rehabilitación y de la calidad de supervivencia.

Descriptores: Paciente; Estoma; Autocuidado; Personas con Discapacidad; Rehabilitación. 


\section{INTRODUCTION}

After the surgical procedure, a change occurs to the healthy body of the person with an intestinal ostomy, and they may develop feelings such as shame, insecurity, vulnerability, and non-acceptance of their new condition, despite understanding the need for making this stoma for the resolution of their health problem $^{(1-3)}$. Still, the use of a waste output equipment makes social interaction difficult due to the concern with elimination of gases, odor, leakage of feces, and physical discomfort, adopting an attitude of distancing themselves from daily activities, socially and work isolation, resulting in retirement due to disability and changes in daily routine, which makes rehabilitation difficult ${ }^{(1-6)}$.

Such transformations put into perspective the physical disability of these people, being that the self-care with the intestinal ostomy and the handling of the waste output equipment assume a central role in their lives - aspects focused in this study through the research question: "What is the perspective of the person with intestinal ostomy pertaining self-care and handling of the waste

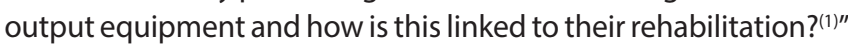

The experience of self-care of these people is influenced by family support, by significant people, as well as by the specialized support of health professionals to achieve rehabilitation and adaptation to their new condition ${ }^{(1-3,7-8)}$. Despite this, self-care, which is the start of the rehabilitation process, is not facilitated, as the repercussions of this deficiency in people's lives constitute social barriers in resuming their daily lives.

The rehabilitation of the person with intestinal ostomy has been linked more towards the physical aspect, however there is a need to plan assistance by integrating physical care with the psychological, cultural, labor, social, and sexual aspects (1-3,9-11). $^{\text {. }}$

For this study, we adopted the theoretical framework of the Social Model of Disability ${ }^{(12)}$, which started by Paul Hunt in the United Kingdom, which is justified by the contribution in the interpretation of the physical disability of these people by recognizing that the injured body is linked to situations or conditions imposed by the social structure, considering physical aspects, social barriers, and health care contexts ${ }^{(1-2,12)}$. However, the challenge lies in legitimizing collective actions and to repair social inequality, as well as biomedical care to integrate the disability into the person with the modified condition's lifestyle $\mathrm{e}^{(1-2,12)}$, directly influencing self-care and consequently, the reach of rehabilitation.

This will contribute to the planning of specialized assistance to achieve rehabilitation in order to make the person with intestinal ostomy as independent as possible, analyzing the conditions and limitations for self-care with the ostomy and handling of the waste output equipment, which represent a first aspect, but should not be considered as the only one or the most important ${ }^{(10)}$. The priority must be on actions to regain control of one's life, with an analysis of the limitations of aptitudes, which should be signaled by the person who experiences the illness and ostomy ${ }^{(1-3,13-14)}$.

\section{OBJECTIVES}

To interpret the self-care experience of people with intestinal ostomy registered in an ostomy program, based on the framework of the Social Model of Disability.

\section{METHODS}

\section{Ethical aspects}

The study was developed according to Resolution 466/2012(15) and approved by the Research Ethics Committee of the Ribeirão Preto School of Nursing. People with intestinal ostomy were invited to participate and received an explanation of the research objectives, as well as formalization of participation by signing the Informed Consent Form (ICF); confidentiality of information and preservation of anonymity was maintained through the sequential alphanumeric coding of names (PE1 to PE9). It was explained that the refusal to participate would not result in an interruption of care or treatment in the specialized health service.

\section{Theoretical-methodological framework}

The Social Disability Model framework ${ }^{(12)}$ was used to interpret the self-care experience with the intestinal ostomy and the handling of the waste output equipment of the participants in this study. Thus, physical disability and its daily repercussions became evident, which constituted physical, social, and labor barriers, including within the contexts of health care. The removal of such barriers enabled the adoption of a new lifestyle, to achieve the rehabilitation of these people $e^{(1,12)}$.

\section{Type of study and Methodological procedure}

Qualitative exploratory study resulting from a mixed design study ${ }^{(16-17)}$, whose methodological rigor of qualitative research followed the COREQ (Consolidated Criteria for Reporting Qualitative Research) checklist, recommended by the EQUATOR Network ${ }^{(18)}$.

The data collection for the interpretation of the experience of self-care of the intestinal stoma and the handling of the waste output equipment, an in-depth interview using the focus group (FG) technique, participant and non-participant observation, in addition to the field diary, were used, demonstrating to be essential for data triangulation ${ }^{(1,19-20)}$.

Aiming at conducting the FG interview, the team was composed of a moderator with extensive clinical experience in assisting people with ostomy and qualitative research, in addition to three observers (stoma nurse, nurse, and psychologist). This composition ensured systematic data collection, with each observer focusing on a specific aspect, respectively: self-care with the ostomy and handling of the waste output equipment; activities of daily living; and psychological aspects. All researchers had clinical experience with the theme of the study, and the main researcher was linked to the participants due to her voluntary work as a stoma nurse in the Ostomy Association ${ }^{(1)}$.

The study was carried out at the regional service center for people with ostomy, which is composed by 90 municipalities in São Paulo and carries out 270 services/month by supplying waste output equipment and adjuvants, as well as the performance of a multi-professional team.

In the first quantitative stage of this mixed study, 120 people with intestinal ostomy responded to the revised Appraisal of SelfCare Agency Scale for people with chronic conditions, validated 
for Brazilian Portuguese ${ }^{(21)}$, with a numerical linear scale from 0 to 75 points, classified as: absent capacity for self-care (15-30 points); partial capacity (3145 points); and full capacity (46-75 points). Considering that this put into scale the capacity for general selfcare, a specific instrument was designed and validated for the evaluation for self-care of the intestinal stoma, with a capacity rating, absent for self-care ( 0 to 5 points), partial capacity (6-10 points), and full capacity for specific self-care (11-15 points). This step was carried out with the assistance of a researcher specialized in quantitative instruments ${ }^{(1)}$.

The selection criteria for the participants to compose the FG were: people with intestinal ostomy, adults, and elderly, registered in the specialized care center, of both sexes, residing in a geographical area up to $50 \mathrm{~km}$ from the study site, which had participated in the first stage of the study, classified in one of the three subgroups: full capacity for self-care; partial capacity for self-care; or absent capacity for self-care ${ }^{(1)}$.

The invitation to the FG participants took place through a home visit with delivery of the participation date in writing and, on the eve of the date of the FG, by telephone contact. Three consecutive monthly meetings were held, lasting between one and two hours, with audio recording as authorized by the participants. The meetings took place at the Association of Ostomy Patients, through previous scheduling according to the availability of the participants.

For the FG interview, the coordination team prepared a guide with specific objectives for each meeting. The guiding question and the objectives of the meetings were defined by analyzing the data of each FG and by the discussions in the meetings of the coordinating team, before and after each meeting.

Thus, the guiding questions were:"What has your experience with colostomy care and ostomy bag been like?" (first FG); "For you, what was it like learning how to replace the ostomy bag?" (according to FG); "How do you see your life with the ostomy bag?" and "The care for the ostomy bag, carried out by yourself or someone else, what does it mean to you?" (third FG) ${ }^{(1)}$. The term "ostomy bag" was used, as this is how the waste output equipment was referred to within the service center.

Data collection occurred among nine people with intestinal ostomy, and the use of the guide focused on the topic under discussion by the moderator and the notes taken by the observers, both for deepening and clarifying the topic under discussion (with requests for contextualization of situations and experiences of the participants in each meeting) and for the resumption of aspects to deepen the theme in each FG. The observations of the sessions complemented the analysis of the audio recordings of each FG. At the end of each meeting, a synthesis was prepared, ensuring that the participants could voluntary express themselves, to add, clarify, or modify aspects reported during the discussion or feelings about the group and their participation ${ }^{(1)}$. At the end of each session, a moment of socialization was promoted among the participants, with a snack.

\section{Data analysis}

The data were analyzed using Inductive Content Analysis, according to the Thematic Analysis proposal by transcribing the data in the form of texts, reading for categorizing the data, establishing themes, and interpreting the participants' experience, based on the referential of the Social Model of Disability ${ }^{(1-2,12,22)}$.

\section{RESULTS}

Nine people with intestinal ostomy participated in the FG: five males and four females, with an average age of 60.7 years, with schooling ranging from incomplete elementary education to complete higher education. Most were married, retired, and on leave from work due to illness, with a family income between two and ten minimum wages, in addition to cohabiting with a family member ${ }^{(1)}$.

Regarding the clinical characterization, five participants had colostomy and four ileostomy, and the duration of ostomy varied between 10 months and 30 years, whose diagnoses were colorectal cancer and inflammatory bowel disease. In addition, six had ostomy complications such as retraction and parastomal hernia, and only two had the ostomy demarcation. As for the waste output equipment, seven used the two-piece equipment, associated with protection and safety adjuvants ${ }^{(1)}$.

When assessed on the specific self-care ability with the ostomy and handling of the waste output equipment, five showed full capacity; two, partial capacity ${ }^{(1)}$, which included stoma hygiene care, observation of the ostomy and peristomal skin, as well as removal of the equipment; and two, absent capacity for self-care, that is, they performed only the emptying and cleaning of the waste output equipment.

The experience of these people with regard to self-care with ostomy was categorized under the theme"The experience of the need for self-care after the process of intestinal ostomy", estimating the simplistic view of procedural self-care in two thematic areas "Interdisciplinary assistance necessary for people with intestinal ostomy" and "Self-care for the rehabilitation of the person with intestinal ostomy"(1).

\section{Thematic group 1: "Interdisciplinary assistance needed for people with intestinal ostomy"}

During the perioperative hospital care, people with intestinal ostomy went through different clinical situations, determining the first approach to their new condition, that of a person with a physical disability. The professional support offered in this context favored their preparation to be able to deal with ostomy, influencing their willingness to assume self-care (Field diary).

For these people, after the process of intestinal ostomy, the main challenge after discharge from the hospital was to perform self-care with the ostomy and to handle the waste output equipment ${ }^{(1-3)}$. However, in many situations, self-care was not something taught by the hospital:

We left the hospital without any information; you go out with the bag [Field diary: colostomy] on your body and you are not given any spares. As we had no guidance and my wife did not have any practice [...], we did not know the types of foods we could eat, we ate all sorts of food, then the feces came out liquid and it leaked [Field diary: it would infiltrate and the base of the equipment peeled off], burned the skin [...] at first, it was complicated. 
(PE2, male, 65 years old, married, ulcerative colitis, permanent ileostomy and retired)

The clinical condition, the therapeutic repercussions and their consequences were decisive for the understanding of the illness of the person ${ }^{(1)}$ with ostomy resulting from oncological disease, supporting their pessimistic perspective on ostomy, as well as the certainty of the impossibility of assuming self-care due to its clinical severity:

I had the first surgery in my city, and there was no need to use the bag, but I had chemotherapy and radiation therapy. Radiotherapy reduced the second tumor, but it also affected a large part of my intestine. The last surgery was at the end of 2008, I did five surgeries [...] I put the bag on and then six months later I made the reversal, but I had a rectovaginal fistula. (PE9, woman, 69 years old, divorced, cancer, permanent colostomy and retired)

On the other hand, people with inflammatory bowel disease revealed a positive outlook on illness compared to those with neoplasia, favorably influencing them to assume self-care. This distinction was tied to the fact that, for the person with inflammatory bowel disease, surgery with an intestinal ostomy had a connotation of saving their life, due to the suffering for many years with intense crises of pain and diarrhea, with alternating periods of remission and exacerbation. For them, the ostomy made it possible to start a new life, with an optimistic view of their condition, and this made them assume self-care, as the ostomy was integrated into their body ${ }^{(1)}$ :

This [Field diary: ileostomy] is not a problem [...] it is a life solution [...] it's bad having it [Field diary: ileostomy], it's worse without it! I am healthier now, 30 years after the ostomy, than when I was back at the beginning. I was skin and bone, very thin. This year marked 30 years since the procedure! [...] / faced the problem, I didn't back down from the stoma, I didn't go into depression, I didn't hide at home, I went out, I kept going out with my friends to dance just as before [Field diary: from illness]. (PE1, woman, 63 years old, married, Crohn's disease, permanent ileostomy and retired)

In addition, ostomy had great psychosocial repercussions, as it affected the way people with an ostomy were seen by others in different social spaces (leisure, work, and health institutions). They suffered prejudice and social exclusion due to the population's lack of knowledge about intestinal ostomy as a physical disability, as defined by Brazilian legislation ${ }^{(1)}$. On the other hand, there was self-prejudice towards their new condition, which further increased suffering ${ }^{(1)}$ :

I approach my girls and ask, "I don't smell, do I? Come and sniff your mom." [...] lol [Field diary: laughs of embarrassment]. "Come check if your mom doesn't stink, if I do, please tell me." (PE4, woman, 47 years old, widow, neoplasia, permanent colostomy and on sick leave)

Perioperative care focused on the procedural issue, with a functional biomedical view of the body, and the need for care excluded the repercussions on other aspects of these people's lives. Disability was not discussed in such a context; and, rarely, the necessary adaptations for a new lifestyle were addressed (Field diary) $)^{(1)}$.

\section{Thematic group 2: "Self-care for the rehabilitation of the person with intestinal ostomy"}

For people with intestinal ostomy to take responsibility for self-care, they had to deal with the self-prejudice and stigma of being physically disabled. Many developed strategies, such as the adoption of rituals and habits, that gave them a sense of security to achieve self-care with the ostomy and management of the waste output equipment, despite recognizing that such solutions were not always scientifically based. Complete self-care was understood as their redemption before society, despite being a person with a disability ${ }^{(1)}$. In other words, it is as if their independence for self-care minimized the impossibility of meeting social expectations, prior to ostomy ${ }^{(1)}$ :

First I take a shower, take care of my full hygiene, I scrub around it close to 100 times before putting it on [Field diary: base of the waste output equipment], 50 times rubbing it on the wall and another 50 times [...] compulsively, I believe it is psychological, I think it works, lol, everyone has a habit for feeling safe. I feel safe this way. (PE3, male, 51 years old, married, neoplasm, temporary colostomy and on sick leave)

I try to take a little sunbath; at my house, my room gets some afternoon sunlight from the window, so it works out. (PE2, male, 65 years old, married, ulcerative colitis, permanent ileostomy and retired)

Access to specialized perioperative assistance enables the construction of a stoma favorable to self-care, with demarcation of the ostomy to prevent its complications and peristomal skin in the postoperative period, facilitating the learning of specific ostomy care and handling of the waste output equipment. It is noteworthy that six people had ostomy complications, and they had not had access to specialized assistance with the demarcation and needed the help of a family caregiver in the care ${ }^{(1)}$ :

My wife always changed it, she was always, always changing it such that I got used to it and then I had the hernia problem [...] I don't know how this hernia came about, because I didn't force it. Sometimes, I will change it, but she can change it in a minute. (PE6, male, 63 years old, married, neoplasia, permanent colostomy and retired due to disability)

I thought they made my stoma very close to the navel, so the bag does not stick completely on this side of the navel, the navel hole is left out. (PE4, woman, 47 years old, widow, neoplasia, permanent colostomy and absent from work due to illness)

The resolution of difficulties was achieved through adherence to a new lifestyle after illness, which had repercussions on food and new behaviors for their health, such as the abandonment of addictions (alcohol and cigarettes) ${ }^{(1)}$. However, the self-prejudice about his new condition and the need for ostomy self-care and the handling of the waste output equipment arose, due to the resumption of activities of daily life ${ }^{(1-2)}$ : 
When I had the ostomy, I smoked and drank; the doctor said I would have to stop, quit smoking and drinking, then I did. When I travel, I try to eat as little as possible, almost nothing at all [...] you have to take care of yourself, because it you are on a bus and suddenly, let go of your intestines, where are you going to wash it? The bus stops for 10 minutes at the stations, then, when I travel, I stop eating two days before. (PE6, male, 63 years old, married, cancer, permanent colostomy and retired due to disability)

Regarding the achieved adaptations, these occurred over time, which involved the management of ostomy complications to enable the management of the waste output equipment; adaptation in clothing, looking for comfortable clothes that disguised the waste output equipment in public ${ }^{(1-2)}$. Still, there was a control of food on occasions such as trips, consultations, and social activities, so that the intestine would not work, as public facilities did not favor the cleaning of the equipment. Such adaptations represented the adoption of a new lifestyle by these people ${ }^{(1-2)}$. Therefore, the possibility of choosing the type of waste output equipment was essential for maintaining daily activities ${ }^{(1)}$ :

I use the two-piece drainable pouch because I haven't adapted to the one-piece pouch; I go about my daily activities and it doesn't disturb me at all, I'm satisfied. I don't like the transparent bag. (PE2, male, 65, married, Ulcerative Colitis, permanent ileostomy and retired)

Among the unresolved difficulties, the stigma of oncological disease and illness stood out; and prejudice and social exclusion resulting from disability (intestinal ostomy), which many did not consider as part of their new life ${ }^{(1-2)}$. The resolution of such difficulties was more complex, as it did not depend exclusively on the will and the need for adaptation of these people, but it required professional support, with the implementation of social and collective interventions ${ }^{(1)}$ :

My husband, when I met him, he wore the bag out of his pants, so you saw the bag, which was bulking [...] I told him not to use the bag like that anymore. I made him put the bag inside his pants, his shirt on top and little by little I managed to get him to put his shirt inside his pants and that would let it looser [...] he went everywhere, we went to the ball, we did everything [...]. (PE1, woman, 63 years old, married, Crohn's disease, permanent ileostomy and retired)

\section{DISCUSSION}

The sociodemographic and clinical data of the participants in this study corroborate other studies ${ }^{(1,4-6)}$ : majority were elderly, married, with low educational background, retired, low family support and income, which can influence access to information, influence their ability to learn self-care, as well as to adopt adaptations regarding their disability. This will also have an impact on their overall understanding of specific rights as a person with a disability or a person with oncological disease, and not only regarding general Brazilian legislation ${ }^{(12)}$.

In the perioperative care offered to these people, the functionalist and procedural view of surgical treatment prevailed, with reduced care for them when taking care of the intestinal ostomy and handling the waste output equipment. However, it is an abrupt change, generating repercussions in all aspects of life, which implies the need for interdisciplinary assistance, which will influence their perspective towards self-care ${ }^{(1)}$.

In the "Interdisciplinary assistance necessary for people with intestinal ostomy" group, the difficulties faced by them put the demand for specialized assistance in perspective, with a plan to meet individual needs during surgical treatment and outpatient follow-up ${ }^{(1-2)}$. Family members should be included in this planning, as they are fundamental in the physical and psychosocial recovery of the person with an ostomy, assisting them in caring for the ostomy and in handling the waste output equipment at home ${ }^{(1-3)}$.

The suffering position was seen by these people as a normality of their life; however, such normality included all the changes that occurred with ostomy ${ }^{(1-11)}$. The lack of real understanding of this referred normality can compromise professionals' assessment of the adaptation and rehabilitation achieved by these individuals.

In the "Self-care for the rehabilitation of people with intestinal ostomy" group, the different situations that compromised the lives of these people constituted the challenges to be overcome by them. Ostomy self-care became the central aspect in their lives and of their families, as well as specialized assistance and the acquisition of waste output equipment and adjuvants became essential for their survival(1-3).

The ostomy process in the hospital context requires specialized assistance, with preoperative planning, with the preparation and teaching of the patient/family about the surgery and its consequences, in addition to the demarcation of the ostomy; and, in the postoperative period, it implies resuming self-care with the ostomy and handling the waste output equipment, as well as counter-referral to the Ostomy Program of the Brazilian Unified Health System (SUS) or to the outpatient clinic of the supplementary health insurance ${ }^{(1-3)}$. This planning and implementation of assistance to the person with an intestinal ostomy will enable physiological and psychosocial recovery, with an increase to the pervasiveness of rehabilitation ${ }^{(2,3)}$. However, self-care was a challenge for people who did not receive specialized assistance ${ }^{(1-11)}$.

In perioperative assistance, perioperative and self-care teaching, in addition to counter-referral, favored the potential of the secondary service to the specialized follow-up in SUS for rehabilitation, and not only for the acquisition of collection equipment. When this possibility does not exist, you can be referred to the ostomy patient's association ${ }^{(23)}$.

For people with inflammatory bowel disease, surgery with ostomy occurs when they no longer respond to clinical treatment, resulting in clinical worsening with the appearance of complications, which prevents the continuation of daily activities ${ }^{(1,24-25)}$.

On the other hand, according to the person sick with cancer, the diagnosis was linked to pain, suffering, and finitude, and the ostomy represented something that would hinder the rest of his life. The clinical evolution with worsening of the oncological disease reinforced this pessimistic view ${ }^{(1)}$. Even for those who managed to achieve a cure, assuming self-care was seen as a problem, as the act of changing the waste output equipment brought the reality of their new condition and that of a person marked by having cancer ${ }^{(1)}$. At this stage, such people may experience feelings of shame and embarrassment for not being able to meet social expectations ${ }^{(1-6)}$. 
After the surgery, the patients went through changes in their life, called "ostomy process", in which a biographical rupture occurs, transforming their view of themselves, as if comparing the "me before" and the "me after" the surgery. They feel as being outside of the "healthy" standard of normality, standardized by society, generating self-prejudice about their condition of having a physical disability after becoming ill. In addition, the participants experienced the cultural stigma of cancer as the worst type of disease ${ }^{(1-5)}$.

This procedural self-care is the beginning of the rehabilitation process, but the challenges, such as prejudice and social stigma of the new condition, in addition to the daily problems, arose during the survival of these people, who needed the support and help of their families and of specialized professionals ${ }^{(1-2)}$. It is noteworthy that, despite the centrality of procedural care in this service, half of the participants in this study did not have the capacity for full self-care. This indicates the need to deepen the knowledge on the meaning of self-care, expanding the perspective for comprehensive self-care and including physical disability in the new lifestyle $\mathrm{e}^{(1-2,11-12)}$.

For these people, in the first months of the ostomy process, several unknowns arose about self-care, clothing, food, and ostomy complications, which influenced the maintenance of their daily activities and resulted in self-prejudice and social isolation ${ }^{(1-2,7,14,26)}$.

In order to deal with the situation of changing the equipment, they adopted rituals to be safe during self-care. These unknowns can be justified as a reflection of the procedural focus of teaching self-care in the intra-hospital context, which valued the physical aspect, restricting care to the "stages of the waste output equipment", without addressing the psychosocial aspects or identifying the demands of the patient ${ }^{(1-3,11)}$.

The behavior of professionals who focused on procedural self-care ${ }^{(1-2)}$ reflects the hegemony of the biomedical model, whose action denotes a morpho-functional interaction ${ }^{(27)}$; that is, it directs the resolution of the injury, and the psychosocial aspects are not considered in the assistance of these people, making it difficult both to adapt to the condition of a person with a disability (intestinal ostomy) in all areas of life and the extent of their rehabilitation ${ }^{(1,12-13)}$.

A psychological intervention must be offered during the surgical treatment for this clientele; however, in general, it is not considered ${ }^{(3-5,28-29)}$, just as family members are usually not included in the care process.

In the beginning, the ostomy process is individual, as each one has their own intrinsic time to adapt and reform their lives ${ }^{(1)}$, depending on their needs. Self-care is essential to achieve physical and psychosocial adaptation, which involves considering all the aspects of their lives ${ }^{(2,13)}$. Therefore, self-care becomes a collective process, with the participation of the sick person, family members, and health professionals, in a social context.

Daily experience and self-reflection on the repercussions of their illness and ostomy can lead to a reconfiguration of the self, which is the way in which people face life after the ostomy, as a new normality ${ }^{(1-4)}$; for that, it is necessary to adopt a new lifestyle, overcoming the barriers imposed by disability ${ }^{(1-2,12)}$.

For a specialized assistance, which extrapolates the physical aspects of these people, with the inclusion of all aspects of life, a team composed of a doctor, nurse/stomatherapist, psychologist, nutritionist, and social worker is necessary ${ }^{(1-2,30)}$. In the implementation of this health program, interdisciplinary action is a construction based on the knowledge and experience of each professional, complementing the actions of the other, in order to offer means for the person with intestinal ostomy to reach physical and psychosocial rehabilitation ${ }^{(1-3,30)}$.

However, the interdisciplinary team's approach should include the concept of disability, that is, the planning of perioperative care should consider the person with physical disability (intestinal ostomy), who needs to use waste output equipment, recognizing possible restrictions of the body and the repercussions on their daily lives ${ }^{(1-3)}$.

According to the recommendations of the Social Model of Disability ${ }^{(12)}$, specialized assistance will be necessary for this clientele, including the teaching of ostomy self-care and handling of the waste output equipment, including the psychosocial aspects, which interfere in this person's new lifestyle. In addition, it is necessary to enable the removal of social barriers, which hinder their social reintegration, that is, their rehabilitation and survival ${ }^{(1-2,12,28-30)}$.

Often, looking at the stoma realizes their condition, which is not always understood as the condition of a "person with physical disability"(1-2). In these situations, the assistance of a family caregiver will initially be necessary to carry out self-care ${ }^{(1-2)}$, but this should always be encouraged, so that the person becomes more independent.

On the other hand, it is important to seek new educational technologies to ensure the teaching of procedural self-care, optimizing the time of care and the nurse-patient bond, in order to establish the individual demand in the nursing consultation, which will result in the achievement of comprehensive care to that clientele ${ }^{(31)}$.

Assistance to people with intestinal ostomy is permeated with challenges, which can constitute social barriers related to the prejudice of physical disability, social exclusion, and unprepared health professionals for comprehensive care, compromising physical and psychosocial rehabilitation ${ }^{(1-2,12)}$. These barriers can be removed when people with physical disabilities have their social rights ensured, but, for this, they need to be legitimized by the implementation of public health policies ${ }^{(1-2)}$. However, this is a major challenge, as society has not yet managed to recognize the needs of people with disabilities as legitimate. Public policies have not been ensured in an integrated manner at different levels of health care, which reflect directly in the assistance to these people and their families (1-11,30-31). $^{\text {. }}$

Self-care in its entirety, with the inclusion of all aspects of the life of the person with a stoma and the concept of physical disability, expanded the understanding of the experience of the stoma self-care and the waste output equipment handling. This may favor their independence, making them more secure in resuming daily activities and achieving psychosocial adaptation and rehabilitation ${ }^{(1-2,30-31)}$.

\section{Study limitations}

A limitation of this study was the participants' diversified times of ostomy, between 10 months and 30 years, which influenced the learning experience of self-care, the necessary adaptations, and 
the perspective on the physical disability ${ }^{(1-2,12)}$. Another limitation was the participation of patients from a single regional group of ostomy patients from SUS ${ }^{(1,30)}$; in this sense, in future studies, a broader view can be achieved through the perspective of patients from other regions, to understand the self-care of this clientele and the difficulties linked to the socio-cultural context.

\section{Contributions to the Area}

With the results of this study ${ }^{(1-2)}$, we expect to contribute: 1 ) in proposing strategies and interventions for the comprehensive care of people with intestinal ostomy and their families in the hospital context, in order to enhance the assistance offered by the specialized health program in SUS $(13,30) ; 2$ ) in minimizing social barriers and improving assistance to this clientele, through the perspective of the Social Model of Disability ${ }^{(12)}$; and 3) in permanent education for the implementation of public policies ${ }^{(30)}$.

\section{FINAL CONSIDERATIONS}

Considering their experiences, people with intestinal ostomy due to chronic colorectal disease need assistance from the interdisciplinary team to learn self-care. In teaching comprehensive self-care to this audience, social, and contextual barriers to health care and physical disabilities should be addressed, to extrapolate the reductionist view of care as procedural care, favoring the scope of rehabilitation and the quality of survival, whose interpretation was achieved for the purpose of this study $y^{(1-2,12-13,27,30)}$.

\section{REFERENCES}

1. Sasaki, VDM. Autocuidado com a estomia intestinal e equipamentos coletores: perspectiva das pessoas estomizadas intestinais, familiares e equipe multidisciplinar do Programa de Ostomizados [Tese]. Escola de Enfermagem de Ribeirão Preto, Universidade de São Paulo, Ribeirão Preto. 2018.212 f.

2. Sasaki VDM, Teles AAS, Russo TMS, Aguiar JC, Paraizo-Horvath CMS, Sonobe HM. Care in the Ostomates Programs: the multidisciplinary team's perspective. Rev Rene. 2020;21:e44295. doi: https://doi.org/10.15253/2175-6783.20202144295

3. Sasaki VDM, Teles AAS, Lima MS, Barbosa JCC, Lisboa BB, Sonobe HM. Rehabilitation of people with intestinal stomy: integration review. Rev Enferm UFPE [Internet]. 2017 [cited 2020 Jan 21];11(4):1745-54. Available from: https://periodicos.ufpe.br/revistas/revistaenfermagem/ article/view/15271/18078

4. Lenza NFB, Buetto LS, Vieira FS, Oliveira MS, Teles AAS, Sonobe HM. Necessidades do estomizado intestinal em seguimento oncológico: revisão integrativa. Rev Enferm UFPE [Internet]. 2015 [cited 2020 Jan 21];9(6):8715-24. Available from: https://periodicos.ufpe.br/revistas/ revistaenfermagem/article/viewFile/10649/11668

5. Teles AAS, Eltink CF, Martins LM, Lenza NFB, Sasaki VDM, Sonobe HM. Physical, psychosocial changes and feelings generated by intestinal ostomy for the patient: integrative review. Rev Enferm UFPE [Internet]. 2017 [cited 2020 Jan 21];11(2):1062-72. Available from: https:// periodicos.ufpe.br/revistas/revistaenfermagem/article/view/13477/16185

6. Marques ADB, Amorim RF, Landim FLP, Moreira TMM, Branco JGO, Morais PB, et al. Body consciousness of people with intestinal stomach: a phenomenological study. Rev Bras Enferm. 2018;71(2):391-7. doi:10.1590/0034-7167-2016-0666

7. Freire DA, Angelim RCM, Souza NR, Brandão BMGM, Torres KMS, Serrano SQ. Autoimagem e autocuidado na vivência de pacientes estomizados: o olhar da enfermagem. Rev Mineira Enferm. 2017;21:1019. doi:10.5935/1415-2762.20170029

8. Mota MS, Gomes GC, Petuco VM. Repercussions in the living process of people with stomas. Texto Contexto Enferm. 2016;25(1):e1260014. doi:10.1590/0104-070720160001260014

9. Silva CRDT, Andrade EMLR, Luz MHBA, Andrade JX, Silva GRF. Qualidade de vida de pessoas com estomias intestinais de eliminação. Acta Paul Enferm. 2017;30(2):144-151. doi: 10.1590/1982-0194201700023

10. Kimura CA, Guilhem DB, Kamada I, Abreu BS, Fortes RC. A oncologia ostomizou a percepção dos pacientes sobre a relação sexual como uma dimensão importante na qualidade de vida. J. Coloproctol. (Rio J.) [Internet]. 2017;37(3):199-204. doi: 10.1016/j.jcol.2017.03.009

11. Ercolano E, Grant M, McCorkle R, Tallman NJ, Cobb MD, Wendel C, et al. Applying the Chronic Care Model to Support Ostomy SelfManagement: implications for oncology nursing practice. Clin J Oncol Nurs. 2016;20(3):269-74. doi: 10.1188/16.CJON.20-03AP

12. França TH. Modelo Social da Deficiência: uma ferramenta sociológica para a emancipação social. Lutas Sociais [Internet]. 2016 [cited 2020 Jan 21];17(31):59-73. Available from: http://www4.pucsp.br/neils/revista/vol\%2031/tiago-henrique-franca.pdf

13. Ministério da Saúde (BR). Secretaria de Atenção à Saúde. Diretrizes de atenção à reabilitação da pessoa com traumatismo cranioencefálico [Internet]. 2015 [cited 2020 Jan 21] Available from: http://bvsms.saude.gov.br/bvs/publicacoes/diretrizes_atencao_reabilitacao_pessoa_ traumatisco_cranioencefalico.pdf

14. Rojanasarot S. "The Impact of Early Involvement in a Postdischarge Support Program for Ostomy Surgery Patients on Preventable Healthcare Utilization." J Wound Ostomy Continence Nurs. 2018;45(1):43-49. doi:10.1097/WON.0000000000000395

15. Novoa PCR. What changes in Research Ethics in Brazil: Resolution no. 466/12 of the National Health Council. 2014;12(1). doi: 10.1590/ S1679-45082014ED3077

16. Paranhos R, Figueiredo Filho D, Rocha EC, Silva Jr JA, Freitas D. (2016). Uma introdução aos métodos mistos. Sociologias. 2016;18(42):384411. doi: 10.1590/15174522-018004221 
17. Santos JLG, Erdmann AL, Meirelles BHS, Lanzoni GMMelo, Cunha VP, Ross R. Integração entre dados quantitativos e qualitativos em uma pesquisa de métodos mistos. Texto Contexto Enferm. 2017;26(3):e1590016. doi: 10.1590/0104-07072017001590016

18. Galvão TF, Silva MT, Garcia LP. Ferramentas para melhorar a qualidade e a transparência dos relatos de pesquisa em saúde: guias de redação científica. Epidemiol Serv Saude [Internet]. 2016 [cited 2020 Jan 23];25(2):427-36. Available from: http://www.scielo.br/pdf/ress/ v25n2/2237-9622-ress-25-02-00427.pdf

19. Pope C, Ziebland S, Mays N. Qualitative Research in Health Care: analysing qualitative data. British Med J [Internet]. 2000 [cited 2020 Jan 23];320:114-6. Available from: https://www.ncbi.nlm.nih.gov/pmc/articles/PMC1117368/pdf/114.pdf

20. Mendonça I, Gomes MF. Grupo focal: instrumento de coleta de dados na pesquisa em educação. Cad Educ Tec Soc. 2017;10(1):52-62. doi: $10.14571 /$ cets. v10.n1.52-62

21. Stacciarini TSG, Pace AE. Confirmatory factor analysis of the Appraisal of Self-Care Agency Scale: Revised. Rev Latino-Am Enfermagem [Internet]. 2017[cited 2020 Aug 28];25:e2856. Available in: https://www.scielo.br/pdf/rlae/v25/0104-1169-rlae-25-02856.pdf

22. Souza LK. Pesquisa com análise qualitativa de dados: conhecendo a Análise Temática. Arq. bras. psicol. [Internet]. 2019 [cited 2020 Jan 23];71(2):51-67. Available from: http://pepsic.bvsalud.org/scielo.php?script=sci_arttext\&pid=S1809-52672019000200005\&lng=pt

23. Miller D, Pearsall E, Johnston D, Frecea M, McKenzie M. Executive Summary: Enhanced Recovery After Surgery. Best Practice Guideline for care of patients with a fecal diversion. J Wound Ostomy Continence Nurs [Internet]. 2016 [cited 20120 Jan 23];44(1):74-77. Available from: http://download.Iww.com/wolterskluwer_vitalstream_com/PermaLink/JWOCN/A/JWOCN_44_1_2016_12_07_MARTINS_ JWOCN-D-16-00067_SDC1.pdf

24. Vieira FS, Sonobe HM, Oliveira MS, Lenza NFB, Buetto LS, Lima MS. A vida durante o tratamento clínico da Doença de Crohn. Rev Enferm UFPE. 2012;6:2:288-96. doi: 10.5205/reuol.2052-14823-1-LE.0602201206

25. Vasconcelos RS, Rocha RM, Souza EB, Amaral VRS. Qualidade de vida de pacientes com doença inflamatória intestinal: revisão integrativa. ESTIMA, Braz J Enterostomal Ther. 2018;16: e2118. doi: 10.30886/estima. v16.480_PT

26. Martins LM, Sonobe HM, Vieira FS, Oliveira MS, Lenza NFB, Teles AAS. Rehabilitation of individuals with intestinal ostomy. British J Nurs. 2015;24:S4-S11. doi: 10.12968/bjon.2015.24.Sup22.S4

27. Ayres JRCM. Care and reconstruction in healthcare practices. Interface 2004. [cited 2020 Jan 23];8(14):73-92. doi:10.1590/ S1414-32832004000100005

28. Silva NM, Santos MA, Rosado SR, Galvão CM, Sonobe HM. Psychological aspects of patients with intestinal stoma: integrative review. Rev Latino-Am Enfermagem. 2017;25(2950e). doi: 10.1590/1518-8345.2231.2950

29. Silva NM, Santos MA, Barroso BCT, Rosado SR, Teles AAS, Sonobe HM. Estratégias de atendimento psicológico a pacientes estomizados e seus familiares. Psicol: Ciênc Prof. 2019;39:1-16. doi: 10.1590/1982-3703003178982

30. Ministério da Saúde (BR). Secretaria de Atenção à Saúde. Portaria n 400, de 16 de novembro de 2009 [Internet] 2009. [cited 2020 Jan 23]. Available from: http://bvsms.saude.gov.br/bvs/saudelegis/sas/2009/prt0400_16_11_2009.html

31. Carvalho DS, Silva AGI, Ferreira SRM, Braga LC. Elaboration of an educational technology for ostomized patients: peristomal skin care. Rev Bras Enferm. 2018;72(2):427-34. doi:10.1590/0034-7167-2016-0024 